\title{
A Simple and Efficient Protocol for the Mass Propagation of Vanilla planifolia
}

\author{
Ab Rahman Zuraida ${ }^{1 *}$, Kamarulzaman Hassan Fatin Liyana Izzati ${ }^{1}$, Othman Ayu Nazreena ${ }^{1}$, \\ Wan Sembok Wan Zaliha ${ }^{2}$, Che Mohd Zain Che Radziah ${ }^{3}$, Zainal Zamri ${ }^{3}$, Subramaniam Sreeramanan ${ }^{4}$ \\ ${ }^{1}$ Biotechnology Research Centre, MARDI Headquarters, MARDI HQ, Persiaran MARDI-UPM, Serdang Selangor, Malaysia; \\ ${ }^{2}$ Department of Agrotechnology, Faculty of Agrotechnology and Food Science, Universiti Malaysia Terengganu, Kuala Terengganu, \\ Malaysia; ${ }^{3}$ Faculty of Science and Technology, Universiti Kebangsaan Malaysia, Bangi, Malaysia; ${ }^{4}$ School of Biological Sciences, \\ Universiti Sains Malaysia (USM), Minden Heights, Malaysia. \\ Email: "azuraida@mardi.gov.my
}

Received June $12^{\text {th }}, 2013$; revised July $13^{\text {th }}, 2013$; accepted July $31^{\text {st }}, 2013$

Copyright (C) $2013 \mathrm{Ab}$ Rahman Zuraida et al. This is an open access article distributed under the Creative Commons Attribution License, which permits unrestricted use, distribution, and reproduction in any medium, provided the original work is properly cited.

\begin{abstract}
The present study describes a direct shoot regeneration-based micropropagation procedure for Vanilla planifolia. Two types of explant (i.e. shoot apex and stem nodal segment) were screened for their shoot induction potential following a three-month treatment with 6-benzylaminopurine (BAP) and $\alpha$-Naphthaleneacetic acid (NAA). Results indicated that the shoot apices were poor candidates for shoot induction whereas the stem nodal segments showed potential for shoot initiation at a rate of up to 6 shoots/explant. Stem nodal segments were the most responsive as shoots formed (55 shoots) directly following treatments with $1 \mathrm{mg} / \mathrm{L}$ BAP at half strength MS medium after the third subculture. In addition, more shoots were produced on solid medium treatments compared to the liquid medium treatments in two strengths of mediums tested. Regenerated plantlets derived from the $1 \mathrm{mg} / \mathrm{L}$ of BAP treatment were induced to root following a one month culture in growth regulator-free MS medium. There was $90 \%$ survival rate of the rooted plantlets after acclimatization in the greenhouse. The findings in the present study would be helpful for large-scale mass propagation of $\mathrm{Va}-$ nilla planifolia using this simple and efficient protocol.
\end{abstract}

Keywords: Vanilla planifolia; Mass Propagation; Growth Regulator; In Vitro; BAP; NAA; IBA

\section{Introduction}

Vanilla planifolia, a species of vanilla orchid, is grown for its fruit which yields the vanilla flavour used in foods and beverages [1]. Vanilla is a flavouring and aromatizing vanillin produced naturally, and is considered to be better than its synthetic substitute. The seeds of the vanilla pod are used to flavour ice creams, liquor, soft drinks and candies. Vanilla is also used in the production of pharmaceuticals, cosmetics, tobacco and handicrafts. According to the International Trade Centre, only $30 \%$ of the vanilla world market comprises pure vanilla extract while the remaining consists of synthetic vanilla extract, which is produced from chemical components. Currently, the pure vanilla extract world market is dominated by Madagascar and Indonesia. During the past decade, the increase in health awareness and preference for natural products have strengthened the demand of vanilla beans

"Corresponding author.
[2].

Generally, Vanilla is propagated by the conventional method, i.e. using stem-cuttings. However, this method of propagation is inefficient, time-consuming and uneconomical [3-5]. In order to meet the demand for propagules, rapid micropropagation of this plant is essential. Micropropagation is now the basis of a large commercial plant propagation industry involving hundreds of laboratories around the world. The technology is used to meet market demand for vanilla, and to overcome difficulties in alternative methods of propagation. In vitro multiplication of $V$. planifolia has been reported using the culture of callus masses [6,7], protocorms, root tips [8] and stem nodes [9]. Even though few reports are available on in vitro propagation of vanilla, most of the protocols are complicated and utilise coconut water [3,10,11]. However, as coconut water is currently in demand in the market, it has become too expensive to use in the propagation of vanilla in Malaysia. Moreover, there are very li- 
mited reports on in vitro propagation protocols of $V$. planifolia in Malaysia. Thus, the aim of this research is to establish a simple and efficient micropropagation protocol with further development (third subculture) for plant tissue culture of vanilla for large scale production.

\section{Materials and Methods}

\subsection{Plant Material and Aseptic Culture}

The plant, $V$. planifolia, was grown in a pot for 6 months, and maintained in a glass house for a few weeks prior to explant excision and establishment in vitro. Shoot apices and stem nodal segments were used to initiate shoot culture. These explants were cut into pieces of about $2-3$ $\mathrm{cm}$ and kept in a conical flask. They were then washed in a detergent (Teepol) solution for $20 \mathrm{~min}$. before being rinsed in distilled water. Next, the explants were transferred to a laminar air flow chamber, and sterilized with $20 \%$ of Clorox $^{\circledR}$ containing several drops of Tween- 20 for 5 - 20 min., followed by $5 \%$ of Clorox ${ }^{\circledR}$ for another $20 \mathrm{~min}$. The sterilized explants were inoculated onto MS mediums for different treatments.

\subsection{Establishment and Micropropagation of Shoot Cultures}

All sterilized segments of the explants were cultured individually under aseptic conditions on basal MS medium containing $0.1 \mathrm{~g}$ arginine, 0.1 asparagine, $0.1 \mathrm{~g}$ glutamine, $3.0 \%$ sucrose, $0.3 \%$ gelrite agar for gelling and supplemented with five different concentrations of BAP $(0,1.0$, $2.0,3.0,5.0$ or $10.0 \mathrm{mg} / \mathrm{L}$ ) for shoots initiation. Medium sterilization was performed by autoclaving at $121^{\circ} \mathrm{C}$ for 20 min. $\mathrm{pH}$ was adjusted to $5.7-5.8$ before adding agar. Explants were inoculated in a $150 \mathrm{ml}$ flask containing 40 $\mathrm{mL}$ of the desired medium. The cultures were incubated in a plant growth room maintained at a temperature of $25^{\circ} \mathrm{C} \pm 1^{\circ} \mathrm{C}$ and with $16 \mathrm{~h}$ photoperiod by cool-white fluorescent lamps (1000 - 2000 lux). Observations were recorded at weekly intervals. Results were expressed as the number of shoots per explant and length of the shoots after 45 days of culture.

The increments in shoot multiplication for mass propagation in separate experiments were compared. Shoot initials derived from stem nodal segments were cultured on half or full strength solid MS mediums supplemented with different concentrations of BAP $(1.0,3.0$ or $5.0 \mathrm{mg} / \mathrm{l})$ alone or combined with NAA $(0.5$ or $1.0 \mathrm{mg} / \mathrm{l})$ for shoot proliferation. The treatments were conducted in two mediums, viz. liquid and solid. All the explants were subcultured onto the same fresh medium at 1 month intervals. Results were expressed as percentage of proliferation and number of shoots produced after 30 days of first subculture and third subculture (90 days after first subculture).
The experiment was carried out within $3-4$ months of culture.

\subsection{Rooting of Shoots and Transplantation of Plantlets}

Shoots $(>3.0 \mathrm{~cm}$ long) from the best treatment $(1 \mathrm{mg} / \mathrm{L}$ BAP and half strength MS medium) were cultured on MS medium supplemented with either IBA ( 0.5 and 1.0 $\mathrm{mg} / \mathrm{L})$, or NAA $(0.5$ and $1.0 \mathrm{mg} / \mathrm{L}$ ) or a combination of both. The number of shoots producing roots, as well as the number and length of the induced roots were recorded after 30 days. In vitro raised plantlets were removed from the culture medium and roots were washed under running tap water to remove the agar. Regenerated shoots with well-developed roots were transferred to plastic pots containing hardening medium and a top soilcompost mixture (2:1). They were maintained at about $70 \%$ relative humidity in the greenhouse. The plantlets were hardened for 60 days so that they would be well established. Observations were recorded with respect to the survival rate of plantlets rooted in the acclimatization condition.

\subsection{Statistic Analysis}

All statistical analyses were performed using SPSS software. The experiment followed a completely randomized design, using 15 flasks for each treatment. Each flask contained two samples and all experiments were repeated thrice. The means and standard errors (indicated as \pm values) were calculated for the treatment responses.

\section{Results and Discussion}

\subsection{Shoot Initiation and Micropropagation}

A simple and effective protocol has been developed for the in vitro micropropagation of Vanilla planifolia. Different types of explants (shoot apex and stem nodal segment) were cultured on MS media supplemented with different concentrations of BAP to evaluate their effect on shoot production at the initiation stage. Explants grown on BAP-containing media resulted in varying success in shoot initiation depending on the type of explants cultured. The findings in this study indicated that explants from stem nodal segments performed better in producing multiple shoots compared to those of the shoot apices (Table 1 and Figures 1(a)-(c). Similar results were reported by Malek et al. [12] in their studies on pointed gourd. They observed that the nodal segments showed a higher percentage of shoot induction (98.00\%), shoot number per explant (5.50) and shoot length per explant $(6.55 \mathrm{~cm})$ compared to shoot tip explants. Similarly, according to Hutchinson [13], nodal segments of apple proved to be good explants for micropropagation. These 
Table 1. Effects of type of explants and BAP on the number of shoots/explants and shoot length after a 40-day culture.

\begin{tabular}{|c|c|c|c|}
\hline Type of explants & $\mathrm{BAP}(\mathrm{mg} / \mathrm{L})$ & Number of shoots per explant & Shoot length $(\mathrm{cm})$ \\
\hline \multirow{6}{*}{ Stem nodal segment } & 0 & $2.46 \pm 0.12$ & $2.2 \pm 0.05$ \\
\hline & 1.0 & $6.06 \pm 0.19$ & $4.5 \pm 0.14$ \\
\hline & 2.0 & $3.45 \pm 0.13$ & $3.4 \pm 0.45$ \\
\hline & 3.0 & $3.31 \pm 0.15$ & $3.5 \pm 0.23$ \\
\hline & 5.0 & $2.56 \pm 0.09$ & $2.8 \pm 0.12$ \\
\hline & 10.0 & $1.45 \pm 0.05$ & $1.9 \pm 0.11$ \\
\hline \multirow{5}{*}{ Shoot apex } & 1.0 & $1.0 \pm 0.02$ & $3.1 \pm 0.23$ \\
\hline & 2.0 & $1.56 \pm 0.13$ & $4.1 \pm 0.34$ \\
\hline & 3.0 & $2.10 \pm 0.34$ & $3.3 \pm 0.23$ \\
\hline & 5.0 & $1.60 \pm 0.45$ & $2.6 \pm 0.14$ \\
\hline & 10.0 & $0.89 \pm 0.05$ & $0.9 \pm 0.07$ \\
\hline
\end{tabular}

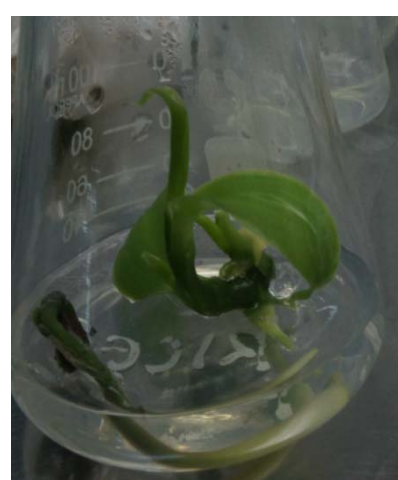

(a)

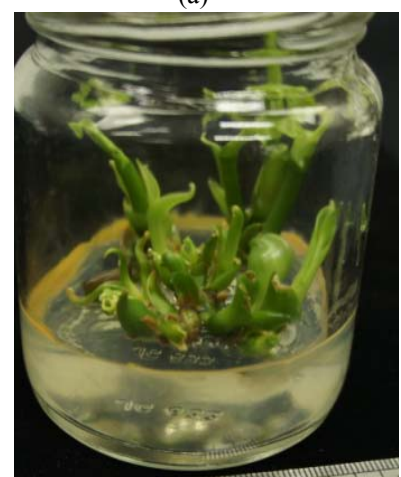

(d)

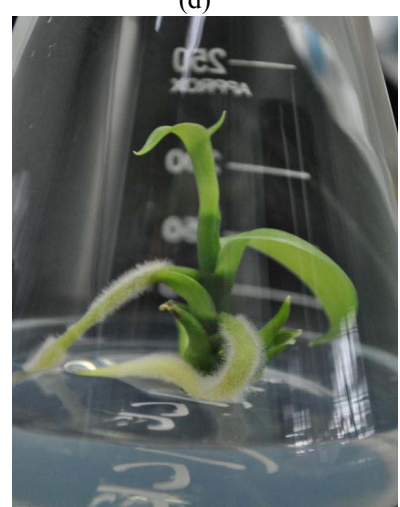

(g)

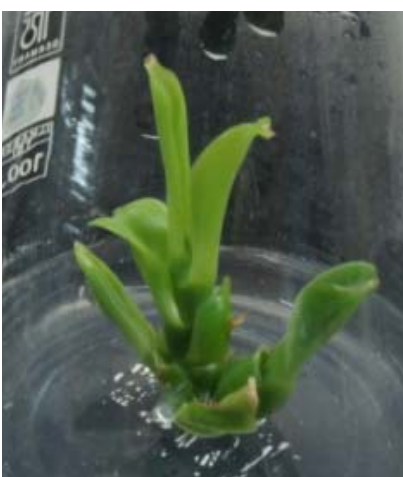

(b)

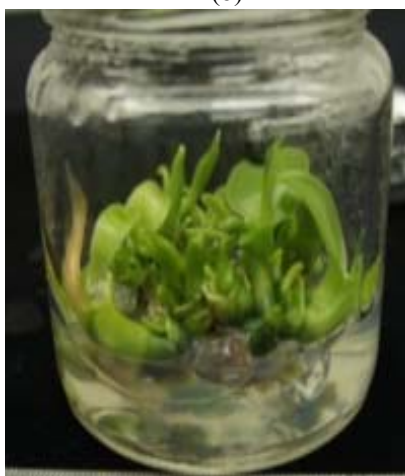

(e)

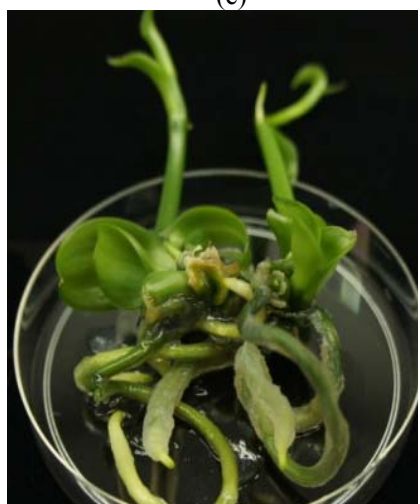

(h)

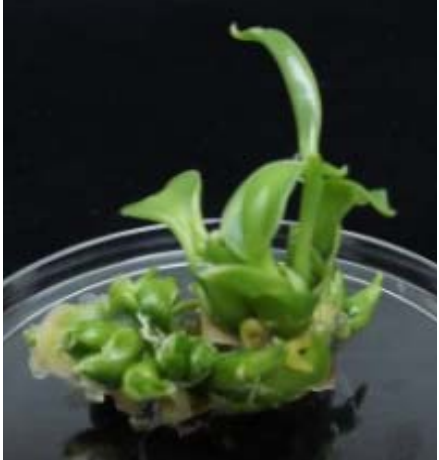

(c)

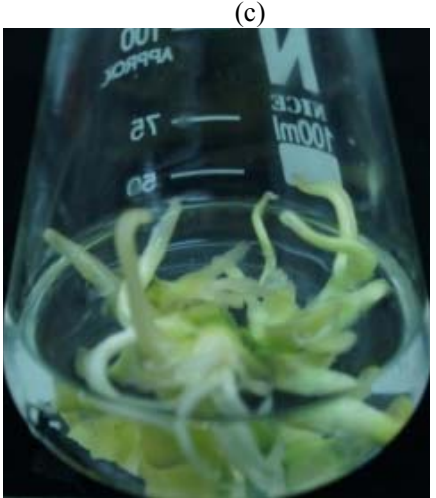

(f)

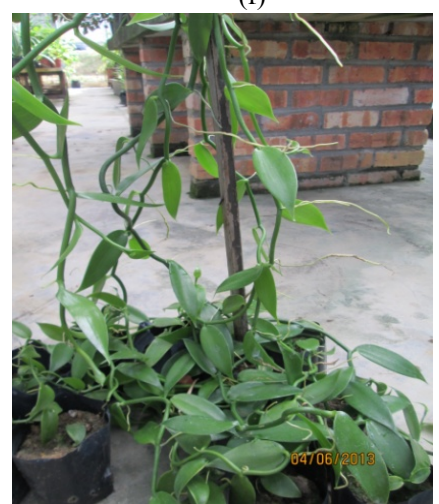

(i)

Figure 1. Micropropagation of Vanilla planifolia on MS medium. Shoot formation from shoot apices (a)-(b), and stem nodal segments (c). Propagation of shoots (d)-(e). Shoots cultured in liquid medium (f). Root initiation and elongation on basal medium (g)-(h). In vitro plant acclimatization, robust growth in the greenhouse (i). 
results also were in agreement with the findings of Zaman et al. [14], which demonstrated the effect of BAP on shoot elongation in nodal segment culture of Verbena spp. It was also observed that MS mediums without any hormone were ineffective in shoot regeneration for all the explants.

The stem nodal segment of $V$. planifolia that was cultured on a medium containing $1 \mathrm{mg} / \mathrm{L}$ BAP showed the highest number of shoots per explant (6.06 shoots), and maximum shoot length $(4.5 \mathrm{~cm})$. Treatments containing BAP with more than $1 \mathrm{mg} / \mathrm{L}$ showed a smaller number of shoots as well as shorter shoot length. The results clearly indicated that shoot proliferation was higher at lower concentrations of BAP, and gradually decreased when BAP concentration was increased. According to Soledad Diaz et al. [15], the suitability of growth regulators depends upon the types of plant tissues or explants used. In this study, the results were in agreement with those obtained by Tan et al. [11], i.e. the highest number of shoots per explant (5.03 shoots) with a mean length of $3.9 \mathrm{~cm}$ was observed from the medium supplemented with $1.0 \mathrm{mg} / \mathrm{l}$ BAP. According to Firoozabady and Gutterson [16], the addition of BAP in MS medium was essential for the regeneration plantlets from shoot apices. This was reiterated by Kalimuthu et al. [3] who stated that a combination of coconut water $(150 \mathrm{ml} / \mathrm{L})$ and BAP $(1 \mathrm{mg} / \mathrm{L})$ was the most effective in shoot proliferation of vanilla from shoot tip and nodal explants.

Shoots from the stem nodal segments of vanilla were cultured on solid or in liquid $(0.7 \%$ agar) MS medium containing different concentrations of growth regulators (BAP and NAA) and varying strengths of MS medium for a 4-week period to compare the effects of these mediums on shoot proliferation. All the treatments showed a proliferation of shoots ranging from $60 \%-100 \%$ (Table 2). Generally, the medium that was supplemented only with $1 \mathrm{mg} / \mathrm{L}$ BAP showed the best results for shoot proliferation $(100 \%)$ when cultured on solid or in liquid mediums, either at full or half strength. However, when BAP treatments were combined with NAA, the result was a decrease in shoot proliferation in all treatments except the treatment with MS liquid medium at half strength. The shoots that were cultured on MS medium containing a higher concentration of BAP $(3-5 \mathrm{mg} / \mathrm{L})$ showed a low level of development. Although multiple shoots were produced, the plantlets were stunted after 4 weeks of culture.

In many plants, the steps for micropropagation protocol require a series of growth regulators. A balance between two groups of growth regulators, viz. auxins and cytokinins, constitutes the most effective group of plant hormones regulating cell division and elongation as well as determining morphogenesis [15]. The use of BAP and NAA in tissue culture media, which are associated with in vitro morphogenetic events and cytokinins, is the most promising in shoot formation. As reported in previous studies, $97 \%$ of the explants produced a mean of 9.6 shoots with a mean shoot length of $4.70 \mathrm{~cm}$ when cultured in a medium containing coconut water with 1.0 mg/l BAP [11]. Findings by Zuraida et al. [17] showed that sub-culture of microshoots in a medium with $1 \mathrm{mg} / \mathrm{L}$ BAP produced the highest proliferation of pineapple plantlets. Furthermore, Alderete et al. [18] reported that the nodal segments of Mecardonia tenella cultured in a medium with $1 \mathrm{mg} / \mathrm{L}$ BAP showed the best multiplication rates, with values around 29 shoots per explant. The positive effect of BAP and NAA in promoting the proliferation of shoots was also detected by Boulay [19], who indicated that the best shoot proliferation of Sequoia sempervirens occurred on MS medium with $0.5-1.0$ $\mathrm{mg} / \mathrm{L}$ BAP and $0.02 \mathrm{mg} / \mathrm{L}$ NAA. As Abebe et al., [20] had done with vanilla planifolia using a combination of 1 $\mathrm{mg} / \mathrm{L} \mathrm{BAP}$ and $1.5 \mathrm{mg} / \mathrm{L} \mathrm{KIN}$, Boulay observed up to 4 shoots from the nodal culture. The number of shoots generated from vanilla explants cultured on the same mediums (as listed in Table 2) was recorded after the first and third subculture. The in vitro plantlets required subculture every eight weeks to remain healthy. The result indicated that the number of multiple shoots was small during initial or first subculture, but increased after the third subculture. After 30 days of first subculture and 90 days of third subculture, the explants that were cultured on a solid medium produced more shoots compared to those in the liquid medium (Figures 1(d)-(f)). It was observed that the physical state of the solid medium affected shoot multiplication. A higher multiplication rate was observed in those treated on solid medium, whereas those continuously cultured in liquid medium resulted in stunted growth and the leaves became whitish and light green (Figure 1(f)). These results are in disagreement with the findings of Tan et al. [11] for vanilla where the liquid MS medium gave higher multiplication rate compared to the semi-solid medium. Zuraida et al. [17] found that with the pineapple plant, shoot multiplication increased up to nine-fold in liquid medium when compared to the cultures maintained on solid medium after the third subculture. According to Hung et al. [21], a liquid medium based culture is a more economical method for mass propagation in a number of plant species.

The explants, when continuously cultured on solid MS medium containing $1 \mathrm{mg} / \mathrm{L}$ BAP with half salt strength and full salt strength, showed a higher number of shoots, producing 17 and 11 shoots respectively after the first sub-culture. A medium containing $1 \mathrm{mg} / \mathrm{L}$ BAP concentration with half salt strength evoked the best response after the third subculture (55 shoots) (Table 2). Incorporation of more than $1 \mathrm{mg} / \mathrm{L} \mathrm{BAP}$ in the third subculture showed improved shoot multiplication but the shoots 
Table 2. Effects of plant growth regulator (BAP and NAA), and strength MS medium on shoot proliferation and number of shoots after being subcultured in solid or liquid MS medium.

\begin{tabular}{|c|c|c|c|c|c|}
\hline \multirow{2}{*}{ MS Solid } & \multicolumn{2}{|c|}{ Plant growth regulator $(\mathrm{mg} / \mathrm{L})$} & \multirow{2}{*}{$\begin{array}{l}\text { Percentage of shoot proliferation } \\
\text { (3 weeks) }\end{array}$} & \multirow{2}{*}{$\begin{array}{l}\text { Number of shoots: } \\
\text { after first sub-culture }\end{array}$} & \multirow{2}{*}{$\begin{array}{l}\text { Number of shoots: } \\
\text { after third sub-culture }\end{array}$} \\
\hline & BAP & NAA & & & \\
\hline \multirow{11}{*}{$\begin{array}{l}\text { Full } \\
\text { salt strength }\end{array}$} & 0 & - & $75 \pm 8$ & $5 \pm 1.5$ & $8 \pm 2.3$ \\
\hline & 1.0 & - & $100 \pm 5$ & $11 \pm 2.4$ & $33 \pm 4.8$ \\
\hline & 3.0 & - & $90 \pm 5$ & $8 \pm 1.5$ & $21 \pm 3.5$ \\
\hline & 5.0 & - & $70 \pm 7$ & $7 \pm 0.9$ & $17 \pm 2.3$ \\
\hline & 1.0 & 0.5 & $85 \pm 8$ & $12 \pm 3.1$ & $21 \pm 4.7$ \\
\hline & 3.0 & 0.5 & $80 \pm 5$ & $8 \pm 1.4$ & $17 \pm 2.8$ \\
\hline & 5.0 & 0.5 & $70 \pm 8$ & $8 \pm 4.6$ & $16 \pm 3.5$ \\
\hline & 1.0 & 1.0 & $85 \pm 3$ & $14 \pm 1.3$ & $17 \pm 2.7$ \\
\hline & 3.0 & 1.0 & $70 \pm 6$ & $8 \pm 2.4$ & $17 \pm 3.7$ \\
\hline & 5.0 & 1.0 & $70 \pm 7$ & $9 \pm 1.9$ & $15 \pm 1.2$ \\
\hline & 0 & - & $75 \pm 9$ & $7 \pm 1.3$ & $18 \pm 1.7$ \\
\hline \multirow{8}{*}{$\begin{array}{c}\text { Half } \\
\text { salt strength }\end{array}$} & 1.0 & - & $100 \pm 4$ & $17 \pm 2.4$ & $55 \pm 4.5$ \\
\hline & 3.0 & - & $90 \pm 3$ & $13 \pm 1.9$ & $31 \pm 3.9$ \\
\hline & 5.0 & - & $70 \pm 8$ & $11 \pm 3.4$ & $28 \pm 2.5$ \\
\hline & 1.0 & 0.5 & $85 \pm 9$ & $13 \pm 2.1$ & $32 \pm 6.9$ \\
\hline & 3.0 & 0.5 & $70 \pm 4$ & $9 \pm 2.3$ & $14 \pm 3.1$ \\
\hline & 5.0 & 0.5 & $65 \pm 3$ & $7 \pm 1.5$ & $12 \pm 1.2$ \\
\hline & 1.0 & 1.0 & $85 \pm 6$ & $8 \pm 1.4$ & $23 \pm 2.4$ \\
\hline & 3.0 & 1.0 & $70 \pm 7$ & $6 \pm 1.2$ & $15 \pm 2.9$ \\
\hline \multirow{3}{*}{ MS Liquid } & 5.0 & 1.0 & $60 \pm 8$ & $6 \pm 1.2$ & $12 \pm 3.4$ \\
\hline & & & & & \\
\hline & 0 & - & $80 \pm 8$ & $5 \pm 0.7$ & $7 \pm 2.0$ \\
\hline \multirow{8}{*}{$\begin{array}{l}\text { Full } \\
\text { salt strength }\end{array}$} & 1.0 & - & $100 \pm 5$ & $9 \pm 1.5$ & $29 \pm 3.5$ \\
\hline & 3.0 & - & $95 \pm 9$ & $8 \pm 1.2$ & $16 \pm 2.1$ \\
\hline & 5.0 & - & $80 \pm 11$ & $3 \pm 0.6$ & $11 \pm 1.2$ \\
\hline & 1.0 & 0.5 & $85 \pm 14$ & $6 \pm 0.5$ & $18 \pm 2.3$ \\
\hline & 3.0 & 0.5 & $70 \pm 12$ & $7 \pm 0.5$ & $17 \pm 1.3$ \\
\hline & 5.0 & 0.5 & $70 \pm 4$ & $7 \pm 1.2$ & $13 \pm 3.4$ \\
\hline & 1.0 & 1.0 & $85 \pm 5$ & $8 \pm 1.5$ & $13 \pm 2.5$ \\
\hline & 3.0 & 1.0 & $75 \pm 7$ & $5 \pm 0.6$ & $14 \pm 2.4$ \\
\hline \multirow{11}{*}{$\begin{array}{l}\text { Half } \\
\text { salt strength }\end{array}$} & 5.0 & 1.0 & $60 \pm 8$ & $5 \pm 0.9$ & $14 \pm 3.1$ \\
\hline & 0 & - & $100 \pm 8$ & $4 \pm 0.8$ & $8 \pm 1.2$ \\
\hline & 1.0 & - & $100 \pm 9$ & $9 \pm 1.4$ & $18 \pm 3.5$ \\
\hline & 3.0 & - & $100 \pm 6$ & $8 \pm 1.6$ & $17 \pm 2.5$ \\
\hline & 5.0 & - & $95 \pm 11$ & $6 \pm 2.3$ & $18 \pm 3.2$ \\
\hline & 1.0 & 0.5 & $95 \pm 6$ & $6 \pm 2.1$ & $16 \pm 2.3$ \\
\hline & 3.0 & 0.5 & $95 \pm 8$ & $4 \pm 0.8$ & $12 \pm 2.6$ \\
\hline & 5.0 & 0.5 & $80 \pm 9$ & $5 \pm 0.6$ & $13 \pm 1.8$ \\
\hline & 1.0 & 1.0 & $100 \pm 6$ & $5 \pm 0.7$ & $13 \pm 1.1$ \\
\hline & 3.0 & 1.0 & $100 \pm 3$ & $3 \pm 1.1$ & $7 \pm 2.3$ \\
\hline & 5.0 & 1.0 & $80 \pm 5$ & $2 \pm 0.5$ & $6 \pm 1.0$ \\
\hline
\end{tabular}


remained stunted. A number of regenerated plantlets that were continuously cultured in liquid medium containing $1 \mathrm{mg} / \mathrm{L}$ BAP with half and full strength MS medium produced 29 shoots and and 18 shoots, respectively for the third subculture. There was rapid shoot multiplication when they were cultured on solid medium containing 1 $\mathrm{mg} / \mathrm{L}$ BAP with half salt strength. Generally, a combination of cytokinin (BAP) and auxin (NAA) in the medium would enhance the multiplication of shoots in the culture. In this study, however, BAP alone proved to be better than its combination with NAA. Firoozabady and Gutterson [16] stated that the addition of BAP in MS medium was essential for the regeneration plantlets from shoot apices. Ammirato [22] reported that the addition of cytokinin at moderate concentrations enhanced shoot development of Dioscorea spp. Abebe et al. [20], in their culture of vanilla, observed clearly separated and fully grown multiple shoots when $1 \mathrm{mg} / \mathrm{L} \mathrm{BAP}$ alone was used, whereas no shoot induction was observed in hormonefree mediums and mediums supplemented with 2 or 3 $\mathrm{mg} / \mathrm{L}$ of BAP combined with different levels of NAA $(0.5,0.75,1.0$ and $1.5 \mathrm{mg} / \mathrm{L})$. This observation is in agreement with the present work.

Based on Table 2, a higher number of shoots were produced in both strengths of MS mediums tested for the third subculture. However, in overall treatments at full strength medium, the number of shoots obtained was less compared to those in half strength medium. This finding was supported by Rafia et al. [23] who stated that the half strength MS with $15 \mu \mathrm{M}$ BAP developed the highest number of shoot buds $(30 \pm 0.6)$ and was superior to full-strength MS with the same level of BAP. As Malek et al. [12] had done with in vitro grown plantlets which had shoot tip explants cultured in half strength MS media supplemented with $2.0 \mathrm{mg} / \mathrm{l} \mathrm{BAP}$ to give the highest shoot induction percentage $(88.00 \%)$, there was maximum number of shoots (4.25) as well as the longest shoot $(4.85 \mathrm{~cm})$. In contrast, Wan Nurul Hidayah et al. [24] reported that the highest number of shoots per explant (32.93 \pm 3.93$)$ was obtained from full strength MS media supplemented with $0.25 \mathrm{mg} / \mathrm{L}$ BAP. Moreover, they stated that the interaction between hormones and the strength of media was also highly significant to the number of shoots produced per explant.

\subsection{Rooting of Shoots and Transplantation of Plantlets}

In order to obtain complete plantlets, in vitro shoot buds were separated and transferred to the rooting mediums. Half or full strength MS mediums fortified with different concentrations of auxins (IBA and NAA) were used for the rooting experiment. Table 3 shows the effect of different concentrations of IBA $(0.5$ and $1.0 \mathrm{mg} / \mathrm{L})$ and NAA $(0.5$ and $1.0 \mathrm{mg} / \mathrm{L})$ on the root formation of vanilla shoot buds. The shoot buds produced roots in both

Table 3. Effect of auxin on root formation from regenerated shoots of $\mathrm{V}$. planifolia.

\begin{tabular}{|c|c|c|c|c|}
\hline MS strength & Treatment of media & Rooted explants (\%) & Number of root per explants & Length of roots $(\mathrm{cm})$ \\
\hline \multirow{8}{*}{$\begin{array}{l}\text { Full } \\
\text { strength }\end{array}$} & MS basal (MSO) & $100 \pm 5$ & $2.8 \pm 0.21$ & $4.52 \pm 0.21$ \\
\hline & $\mathrm{MSO}+$ charcoal & $80 \pm 7$ & $2.7 \pm 0.45$ & $4.31 \pm 0.23$ \\
\hline & $0.5 \mathrm{IBA}$ & $95 \pm 5$ & $2.4 \pm 0.34$ & $3.14 \pm 0.34$ \\
\hline & $1.0 \mathrm{IBA}$ & $95 \pm 8$ & $1.8 \pm 0.11$ & $2.16 \pm 0.09$ \\
\hline & $0.5 \mathrm{NAA}$ & $75 \pm 3$ & $1.9 \pm 0.34$ & $2.16 \pm 0.12$ \\
\hline & $1.0 \mathrm{NAA}$ & $80 \pm 5$ & $2.5 \pm 0.32$ & $2.45 \pm 0.15$ \\
\hline & $0.5 \mathrm{IBA}+0.5 \mathrm{NAA}$ & $85 \pm 7$ & $2.3 \pm 0.15$ & $2.34 \pm 0.18$ \\
\hline & $1.0 \mathrm{IBA}+1.0 \mathrm{NAA}$ & $85 \pm 3$ & $2.1 \pm 0.39$ & $2.56 \pm 0.16$ \\
\hline \multirow{8}{*}{$\begin{array}{c}\text { Half } \\
\text { strength }\end{array}$} & MS basal (MSO) & $100 \pm 8$ & $2.9 \pm 0.12$ & $4.32 \pm 0.11$ \\
\hline & $\mathrm{MSO}+$ charcoal & $100 \pm 5$ & $2.8 \pm 0.45$ & $4.11 \pm 0.17$ \\
\hline & $0.5 \mathrm{IBA}$ & $95 \pm 9$ & $2.9 \pm 0.09$ & $2.81 \pm 0.17$ \\
\hline & $1.0 \mathrm{IBA}$ & $95 \pm 4$ & $2.5 \pm 0.06$ & $2.78 \pm 0.12$ \\
\hline & $0.5 \mathrm{NAA}$ & $85 \pm 6$ & $2.6 \pm 0.17$ & $2.89 \pm 0.14$ \\
\hline & 1.0 NAA & $80 \pm 8$ & $2.1 \pm 0.06$ & $3.21 \pm 0.13$ \\
\hline & $0.5 \mathrm{IBA}+0.5 \mathrm{NAA}$ & $85 \pm 3$ & $2.2 \pm 0.11$ & $2.32 \pm 0.15$ \\
\hline & $1.0 \mathrm{IBA}+1.0 \mathrm{NAA}$ & $85 \pm 9$ & $2.3 \pm 0.12$ & $2.16 \pm 0.09$ \\
\hline
\end{tabular}


strengths of MS mediums tested, ranging from $75 \%$ $100 \%$. Moreover, root induction was strongly stimulated by a growth regulator-free MS medium (Figures 1(g)-(h). Results showed that an auxin-free medium gave the highest percentage of rooting, number of roots and root length in both strengths of MS mediums. Among the auxins tested for root initiation of vanilla, IBA had the greatest effect on rooting, with the high responses up to $95 \%$, as compared to NAA with only $80 \%-85 \%$. The results also showed that the medium containing IBA did not produce very different results, compared to NAA with regard to the number and length of roots.

In the present study, a growth regulator-free MS medium was found to be more effective in root induction. This is in agreement with studies carried out on several plant species, such as A. maximus [25], Phyllanthus species [26], Astragalus adsurgens [27] and A. aquilonius [28]. Abebe et al. [20] observed no difference between growth regulator-free medium and medium supplemented with different levels of NAA $(0.5-1.5 \mathrm{mg} / \mathrm{L})$ for rooting and elongation. Furthermore, Soledad Diaz et al. [15] suggested that NAA incorporated into the medium was not necessary as they found a rooting rate of $90 \%$ was attained when the plantlets were placed in a hormonefree medium. These observations notwithstanding, it is known that auxins, especially NAA, have an inducing effect on rooting under tissue culture conditions [29]. Moreover, according to Majumder et al. [30], the response of shoots to rooting was very much dependent on the concentrations and combination of auxins used. They found that the combination of $1.0 \mathrm{mg} / 1 \mathrm{IBA}+0.5 \mathrm{mg} / \mathrm{l} \mathrm{IAA}$ was the best medium for rooting. The influence of IBA and IAA for root proliferation has been reported in medicinal plants $[31,32]$.

The rooted plantlets were acclimatized successfully when transferred to pots containing a top soil-compost mixture (2:1). The survival rate was $90 \%$ after being kept for a month in a glasshouse (Figure 1(i)).

\section{Conclusion}

A simple and efficient protocol for mass propagation of vanilla was developed by testing various concentrations of growth regulators and nutrition conditions. The process was carried out on in vitro cultures without using expensive materials such as coconut water. Half strength MS mediums supplemented with $1 \mathrm{mg} / \mathrm{L}$ BAP proved conclusively more satisfactory and were sufficient for shoot propagation as well as differentiation at initial stages. It was also concluded that, compared to shoot apices, the stem nodal segments showed higher potential to regenerate. Our investigation also revealed that no auxin supplementation was necessary for rooting differentiation (100\% achieved) in the multiplication of regenerated shoots. Hence, it is a cost effective technique for shoot proliferation of vanilla using nodal segments. This protocol for rapid micro propagation can be utilized for large-scale production of Vanilla planifolia.

\section{REFERENCES}

[1] D. R. Goodenough, "Vanilla, Vanillin and Vanillin Derivatives," Bakers Digest, Vol. 56, 1982, pp. 8-10.

[2] Ranadive and A. S. Vanilla-Cultivaton, "Curing Chemistry, Technology and Commercial Products," Elsevier Scientific Publication, Amsterdam, Vol. 34, 1994, pp. 517 577.

[3] K. Kalimuthu, R. Senthilkumar and N. Murugalatha, "Regeneration and Mass Multiplication of Vanilla planifolia Andr.-A Tropical Orchid," Current Science, Vol. 91, No. 10, 2006, pp. 1401-1403.

[4] P. Ayyappan, "Vanilla-A Money Making Venture for Ambitious Farmers," Kisan World, Vol. 7, 1990, pp. 2426.

[5] D. Knorr, et al., "Biosynthesis and Yield Improvement of Food Ingredient from Plant Cell and Tissue Culture," Food Technology, Vol. 47, No. 12, 1993, pp. 57-63.

[6] Z. Gu, J. Arditti and L. P. Nyman, "Vanilla Planifoiia: Callus Induction and Plantlet Production in Vitro," Lindleyana, Vol. 2, No. 1, 1987, pp. 48-52.

[7] G. Davidonis and D. Knorr, "Callus Formation and Shoot Regeneration in Vanilla planifolia," Food Biotechnology, Vol. 5, No. 1, 1991, pp. 59-66. doi:10.1080/08905439109549791

[8] V. J. Philip and S. A. Z. Nainar, "Clonal Propagation of Vanilla planifolia (Salisb) Ames Using Tissue Culture," Journal of Plant Physiology, Vol. 122, No. 3, 1986, pp. 211-215. doi:10.1016/S0176-1617(86)80119-5

[9] H. Kononowicz and J. Janick, "In Vitro Propagation of Vanilla planifolia," Hort Science, Vol. 19, 1984, pp. 5859.

[10] P. Giridhar and G. A. Ravishankar, "Efficient Micropropagation of Vanilla planifolia Andr. under Influence of Thidiazuron, Zeatin and Coconut Milk," Indian Journal of Biotechnology, Vol. 3, No. 1, 2004, pp. 113-118.

[11] B. C. Tan, C. F. Chin and P. Alderson, "An Improved Plant Regeneration of Vanilla planifolia Andrews," Plant Tissue Culture and Biotechnology, Vol. 21, No. 1, 2011, pp. 27-33.

[12] A. Malek, D. Khanam, M. Khatun, M. H. Molla and M. A. Mannan, "In Vitro Culture of Pointed Gourd (Trichosanthes Dioica Roxb.)," Bangladesh Journal of Agricultural Research, Vol. 35, No. 1, 2010, pp. 135-142.

[13] J. M. Hutchinson, "Tissue Culture: Propagation of Fruit Trees," In: A. N. Roy, Ed., Proceedings of COSTED Symposium on Tissue Culture of Economically Important Plants, Singapore, 1981, pp. 119-120.

[14] A. Zaman, R. Islam, M. Hossain, O. I. Joarder, A. Ahad and A. C. Barman, "Clonal Propagation through in Vitro Shoot Proliferation of Nodal Explants of Seven Mulberry Genotypes," Plant Tissue Culture, Vol. 2, No. 2, 1992, pp. 71-74. 
[15] M. Soledad Diaz, P. Lorena, C. F. Ana and E. G. Marta, "In Vitro Propagation of Muña-Muña (Clinopodium odorum (Griseb.) Harley)," Biotechnology Research International, Vol. 2012, 2012, pp. 1-6. doi: $10.1155 / 2012 / 196583$

[16] E. Firoozabady and N. Gutterson, "Cost Effective in Vitro Propagation Methods for Pineapple," Plant Cell Reports, Vol. 21, No. 9, 2003, pp. 844-850.

[17] A. R. Zuraida, A. H. Nurul Shahnadz, A. Harteeni, S. Roowi, C. M. Z. Che Radziah and S. Sreeramanan, "A Novel Approach for Rapid Micropropagation of Maspine Pineapple (Ananas comosus L.) Shoots Using Liquid Shake Culture System," African Journal of Biotechnology, Vol. 10, No. 19, 2011, pp. 3859-3866.

[18] L. M. Alderete, K. Adriana and S. E. Alejandro, "Establishment of an in Vitro Micropropagation Protocol for Mecardonia tenella," Electronic Journal of Biotechnology, Vol. 9, No. 3, 2006, pp. 263-266.

[19] M. Boulay, "4 Redwood (Sequoia sempervirens)," Biotechnology in Agriculture and Forestry, Vol. 5, 1989, pp. 549-573. doi:10.1007/978-3-642-61535-1 29

[20] Z. Abebe, M. Ayelign, T. Alemayehu and T. Wondyfraw, "Efficient in Vitro Multiplication Protocol for Vanilla planifolia Using Nodal Explants in Ethiopia," African Journal of Biotechnology, Vol. 8, No. 24, 2009, pp. 68176821.

[21] C. D. Hung, K. Johnson and F. Torpy, "Liquid Culture for Efficient Micropropagation of Wasabia Japonica (MIQ.) Matsumura," In Vitro Cellular Developmental Biology-Plant, Vol. 42, No. 6, 2006, pp. 548-552. doi:10.1079/IVP2006805

[22] P. V. Ammirato, "Yams," In: P. V. Ammirato, D. A. Evans, W. R. Sharp, Y. Yamada, Eds., Handbook of Plant Cell Culture, Macmillan, New York, 2004, pp. 329-354.

[23] R. Rafia, N. K. Azra, A. G. Bashir and A. Seema, "Effect of BAP and NAA on Shoot Regeneration in Prunella vulgaris," Journal of Natural Sciences and Mathematics, Qassim University, Vol. 3, No. 1, 2009, pp. 21-26.

[24] W. A. Wan Nurul Hidayah, J. S. Norrizah, S. M. Sharifah Aminah, S. A. Sharipah Ruzaina and P. Faezah, "Effect of Medium Strength and Hormones Concentration on Regeneration of Pogostemon cablin using Nodes Explant," Asian Journal of Biotechnology, Vol. 4, No. 1, 2012, pp. 46-52. doi:10.3923/ajbkr.2012.46.52

[25] N. Turgut-Kara and S. Ar1, "Micropropagation of Astragalus maximus Willd," Biotechnology \& Biotechnological Equipment, Vol. 20, No. 1, 2006, pp. 20-22.

[26] E. Catapan, M. Luis, B. Silva, N. F. Moreno and A. M. Viana, "Micropropagation, Callus and Root Culture of Phyllanthus urinaria (Euphorbiaceae)," Plant Cell, Tissue and Organ Culture, Vol. 70, No. 3, 2002, pp. 301-309. doi:10.1023/A:1016529110605

[27] J. P. Luo and J. F. Jia, "Callus Induction and Plant Regeneration from Hypocotyl Explants of Forage Legume Astragalus adsurgens," Plant Cell Reports, Vol. 17, No. 6-7, 1998, pp. 567-570. doi:10.1007/s002990050443

[28] J. L. Edson, D. L. Wenny, A. Leege-Brusven, R. L. Everett and D. M. Henderson, "Conserving Threatened Rare Plants: Some Nursery Strategies," National Proceedings, Forest and Conservation Nursery Associations, No. 257, 1994, pp. 150-157.

[29] S. P. O. Werbruck and P. C. Debergh, "Applied Aspect of Plant Regeneration (6A. Micropropagation)," In: R. A. Dixon and R. A. Gonzales, Eds., Plant Cell Culture: A Practical Approach, 1994, pp. 127-135.

[30] S. Majumder, M. M. Rahman and S. K. Bhadra, "Micropropagation of Scoparia dulcis Linn. through Induction of Indirect Organogenesis," Asia-Pacific Journal of Molecular Biology and Biotechnology, Vol. 19, No. 1, 2011, pp. 11-17.

[31] A. Biswas, M. Roy, M. A. Bari and S. K. Bhadra, "In Vitro Propagation of Abrus precatorius L.-A Rare Medicinal Plant of Chittagong Hill Tracts," Plant Tissue Culture \& Biotechnology, Vol. 17, No. 1, 2007, pp. 5964.

[32] M. Jawahar, S. Ravipaul and M. Jeyaseelan, "In Vitro Regeneration of Vitex negundo a Multipurpose Woody Aromatic Medicinal Shrub," Plant Tissue Culture \& Biotechnology, Vol. 18, No. 1, 2008, pp. 37-42. 